\title{
The Future Management of Thai Musical Study
}

\author{
Supatra Vilailuck ${ }^{1}$, Supunnee Leauboonshoo ${ }^{1} \&$ Sudarat Janlekha ${ }^{2}$ \\ ${ }^{1}$ College of Music, Mahasarakham University, Khamriang Sub-District, Kantarawichai District, Maha Sarakham \\ 44150, Thailand \\ ${ }^{2}$ Facuty of Humanities and Social Sciences, Bansomdejchaopraya Rajabhat University, 1061 Soi Isaraphab 15, \\ Isaraphab Rd., Dhonburi, Bangkok 10600, Thailand \\ Correspondence: Supatra Vilailuck, College of Music, Mahasarakham University, Khamriang Sub-District, \\ Kantarawichai District, Maha Sarakham 44150, Thailand. E-mail: svilailuck162@hotmail.com
}

Received: July 9, 2014 Accepted: July 17, 2014 Online Published: September 22, 2014

doi:10.5539/ach.v7n1p119 URL: http://dx.doi.org/10.5539/ach.v7n1p119

\begin{abstract}
The two aims of this investigation wereto study the management of Thai musical education and study the trends of Thai musical education management and improvement for the academic year 2013 to the academic year 2022 . Data was gathered using aholistic approach between qualitative analysis and the Delphi method. For the Delphi method, 17 specialists were consulted. The results show that Thai music courses have been prescribed in 3 categories. Courses are assigned containing both theoretical and practical elements by letting the students choose at least one musical instrument as their skill. According to the results, Thai traditional music teaching and learning in the future should be changed to focus onself study. Moreover, information technology must be included in the teaching program in order to improve teaching results.
\end{abstract}

Keywords: musical education, administration, Thai music, tradition, students, curriculum

\section{Introduction}

Modern Thai music majors in graduate study can be divided into two categories: Thai musical instruction and Thai musical performance. Thai musical instruction majorsare controlled and standardized by the rules of the Teacher's Council of Thailand, unlike the Thai musical performance majors, for which the course syllabus can be applied and developed to be suitable to local traditions and collage policy. The Thai musical performance majors are aimed at preserving and inheriting Thai traditional music by focusing on both theoretical and practical study. This research is concerned about the inheritance of Thai traditional music through graduate study of musical performance majors. This investigation aims to collect present data of Thai musical syllabuses and study the trends of Thai musical study improvement for the future.

\section{Research Methodology}

This investigation had two primary study objectives: to study the management of Thai musical education and study the trends of Thai musical education management and improvement for the academic year 2013 to the academic year 2022. Data was gathered using aholistic approach between qualitative analysis and the Delphi method. For the Delphi method, 17 specialists were consulted. The researchers selected the sample population group from Thai musical instructors in 23 government universities focusing on Thai musical performance syllabuses. The research sample was identified using a purposive sampling technique. Field data was collected by survey, observation and interview. All data was categorized according to the aims of the research and analyzed by typological analysis and analytic induction. The results are presented below as a descriptive analysis. This research began in June 2011 and was concluded in May 2012. 
Thai musical study management

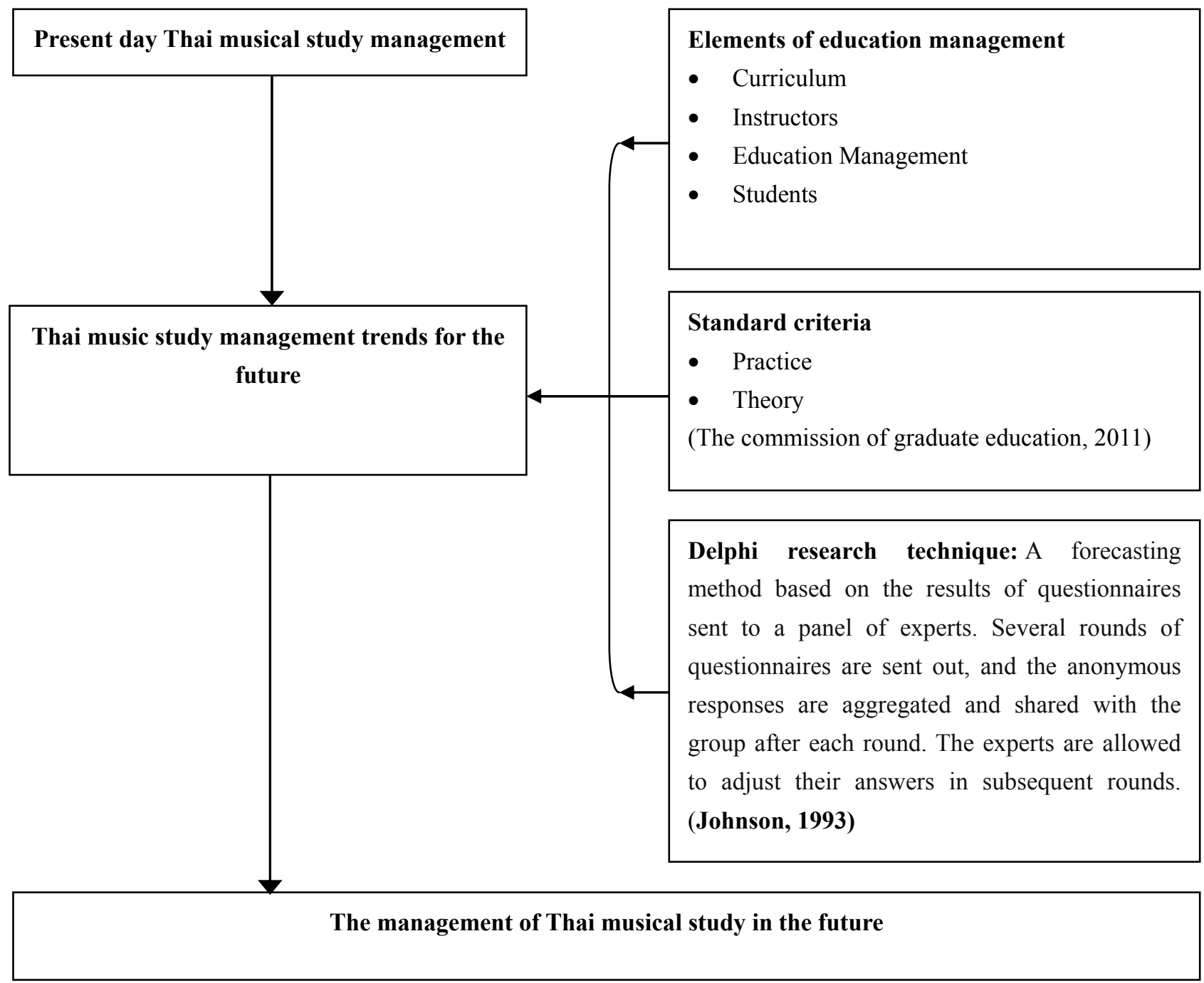

Figure 1.Research framework

\section{Results}

The Thai music study syllabuses focus on producing quality graduates, with high levels of knowledge and skill.There arefive undergraduate Thai music degrees, three of which are equivalent to bachelors of arts, one is the equivalent to a bachelor of music and the fifth is equivalent to a bachelor of literature. Thai music courses have been prescribed in 3 categories:1) Musical study including Thai traditional music as part of the course or a major, for example musicmajors or Thai and Eastern music majors; 2) Musical study prescribed as special Thai musical study, for example Thai music majors, Thai musical art majors and Thai musical instrument majors; 3) Musical study prescribed as Thai musical study as a part of a degree, for example musical study majors included in Thai dancing art department, called Thai music and dramatic arts. The coursesare comprised of both theoretical and practical elements by letting the students choose at least one musical instrument as their skill.Moreover, some parts of the special Thai traditional musical classes have been standardized, since some songs and practices are too difficult to manage because of the different skills of individual students.

The study programs can be divided into 5 groups of subjects: 1) Aesthetic majors, for example the aesthetics of music; 2) Thai traditional theory majors, for example Thai musical theory, the nature and type of Thai traditional music and Thai traditional authorship; 3) Thai traditional music history majors, for example Thai music history, 
Thai musical instrument history and development and Thai traditional music literature history;4) Thai traditional music practice majors, including personal practice, for example Thai traditional musical instrument skills, and group practice, for example Thai traditional music orchestras; 5) Skill improvement subject groups, including Western traditional music theory and skills, for example standard western music theory, other musical instrument skills, for example chorus bands, musical technology skills, for example computers for music development, Thai music teaching skills improvement and Thai music research.

Thai music instructors should acknowledging musical theory, practical skill and teaching skill. Moreover, they should be good precedents for their students. However, the researchers found that a major problem is the lack of teaching staff. TheTeacher's Council standards stipulate thatcurriculum requires at least 5 instructors, resulting in a teaching deficiency.

Modern education management is theoretical, practical and analytical. It includes workshops, self-study, exercises and research. The musical skill improvement has a number of major parts, including classical study, instrument demonstrations and skill exhibitions. The researchers classified Thai music students into 3 groups according to the student ability and knowledge: 1) Students ofmedium-level skill and ability (the largest group of students in Thai musical study majors.) These students have graduated from high school; 2) Students of high skill and ability. Almost all members of this group come from musical families and have inherited skills and techniques from their ancestors; 3) Students of advanced ability who have graduated from music school.

\subsection{Thai Musical Education Trends for the Future}

There are four elements to future musical degree curriculums, as determined by this investigation. Firstly the degree name may change to bachelor of orchestral science. Secondly, the curriculum aims must be to instill the graduate students with traditional Thai knowledge, interpersonal characteristics, information technology ability and expertise in Thai traditional musical instruments. Moreover, the graduates should have good moral principles. Thirdly, each course should have at least 131-135 cumulative credits. Fourthly, Thai musical education should focus on creativity and practice.

The amount of Thai traditional music instructors must increase to meet student demand. The number of musical researchers and developers must also be increased. Moreover, future music instructors should possess good interpersonal relations, creativity and morals.According to the results, traditional Thai music teaching and learning in the future should focus onself study. Moreover, information technology must be included in teaching programs, in order to improve teaching results. Extra-curricular experience activities should be added to Thai musical curriculums, since these activities can not only improve student skill and confidence but also appeal to Thai society.

The Thai traditional music specialists suggested that Thai traditional music education should have benchmarks, which any educational institution could use as a set of guidelines to standardize their curriculums. This suggestion would providea solution to the problem of student skill inequality.

According to the results, the number of students in Thai traditional music majorswill decrease, due to the lack of career path. The traditional Thai music students should be interested in and acknowledge both traditional Thai music theory and practice.The specialists suggested that the candidates should pass skills assessments, for example in traditional Thai singing, traditional Thai musical instrument skills assessments, history and theoretical knowledge.The results show that evaluation of traditional Thai musical education should be concerned with equipment skill and accuracy, singing and application.

\section{Conclusion}

Conclusions from this investigation have been summarized in Figures 2 and 3 (Figure 2; Figure 3). 


\begin{tabular}{|c|c|c|}
\hline 寻 & $\begin{array}{l}\text { Providing both theory and } \\
\text { practicing skill for student } \\
\text { Degree name } \\
\text { Bachelor of Arts } \\
\text { Bachelor of Fine \& Applied Arts } \\
\text { Bachelor of Fine Arts } \\
\text { Bachelor of Music } \\
\text { Bachelor of Arts } \\
\text { The course can be divided to } 5 \\
\text { Thai traditional music practice, }\end{array}$ & 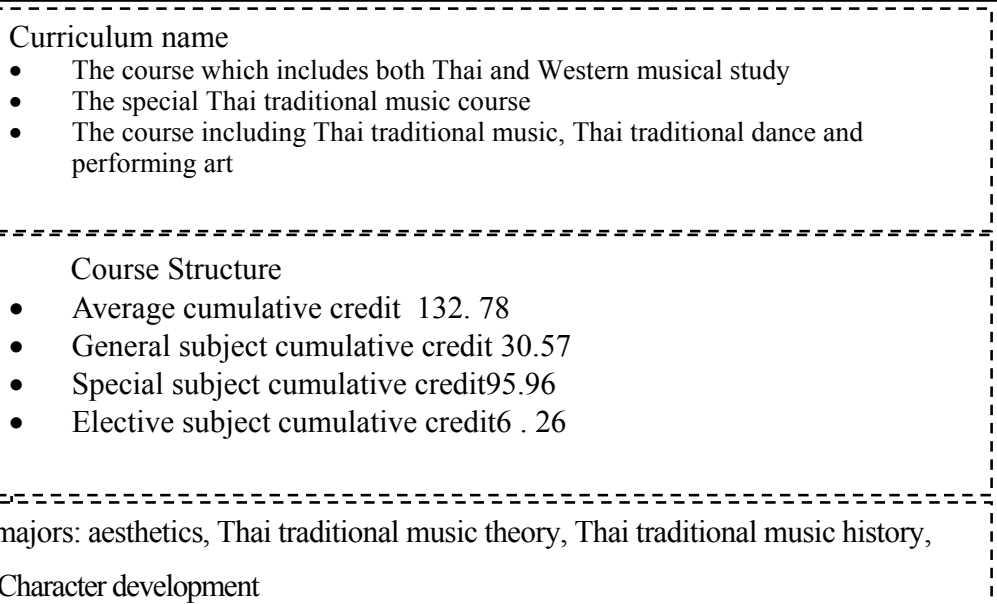 \\
\hline
\end{tabular}

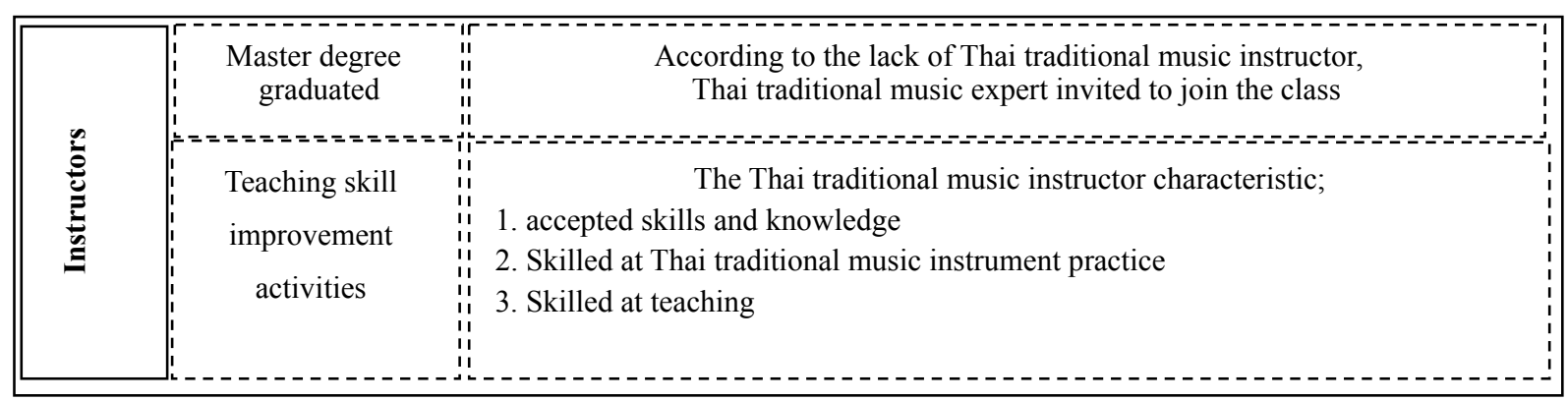

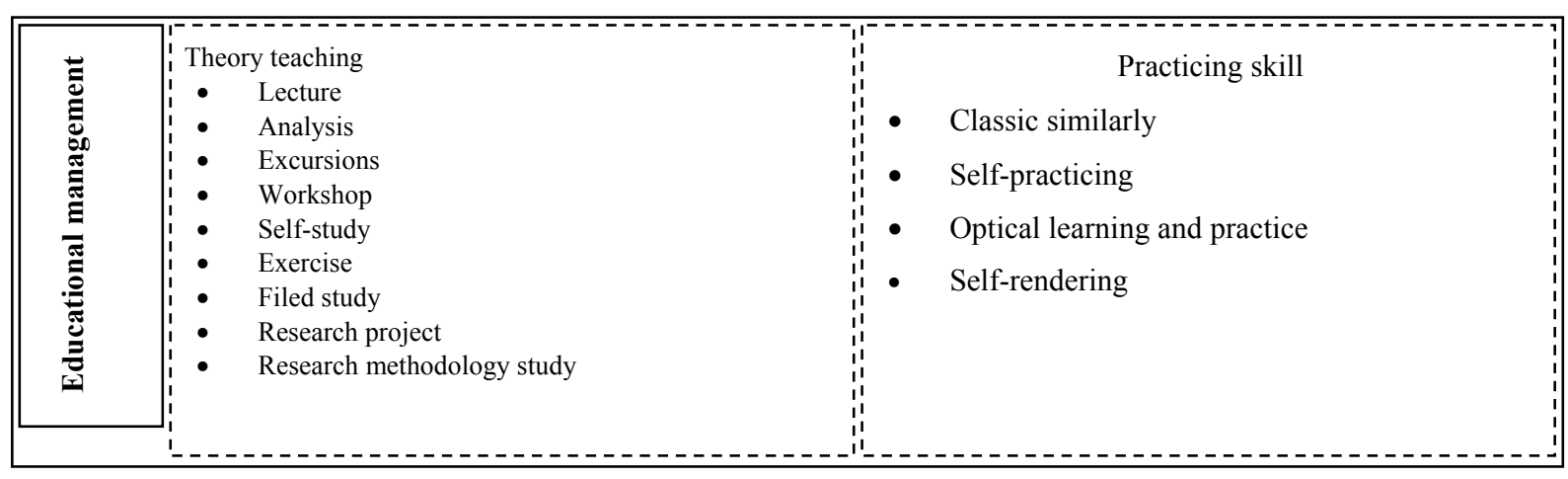

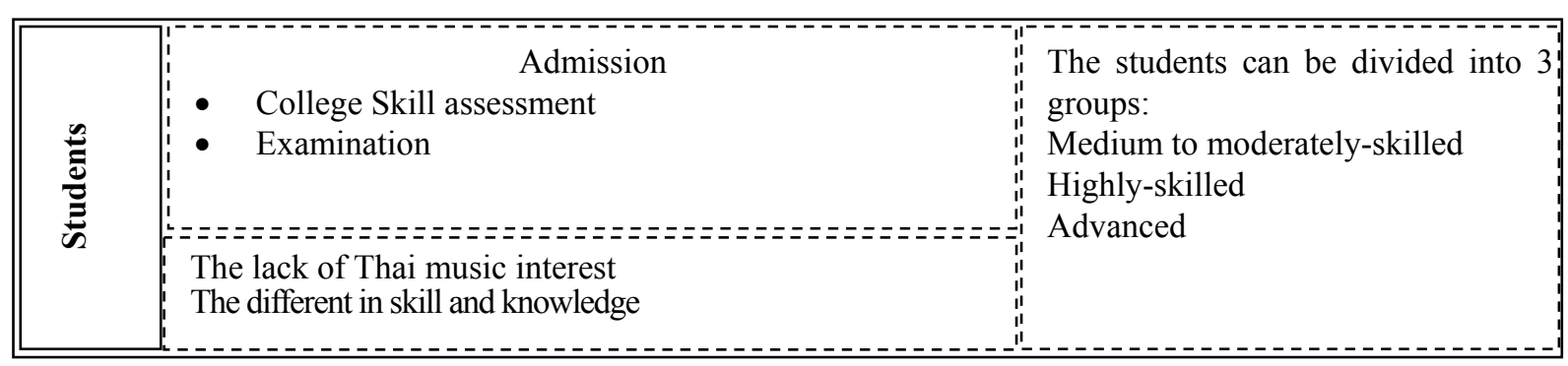

Figure 2. The management of Thai music studies 

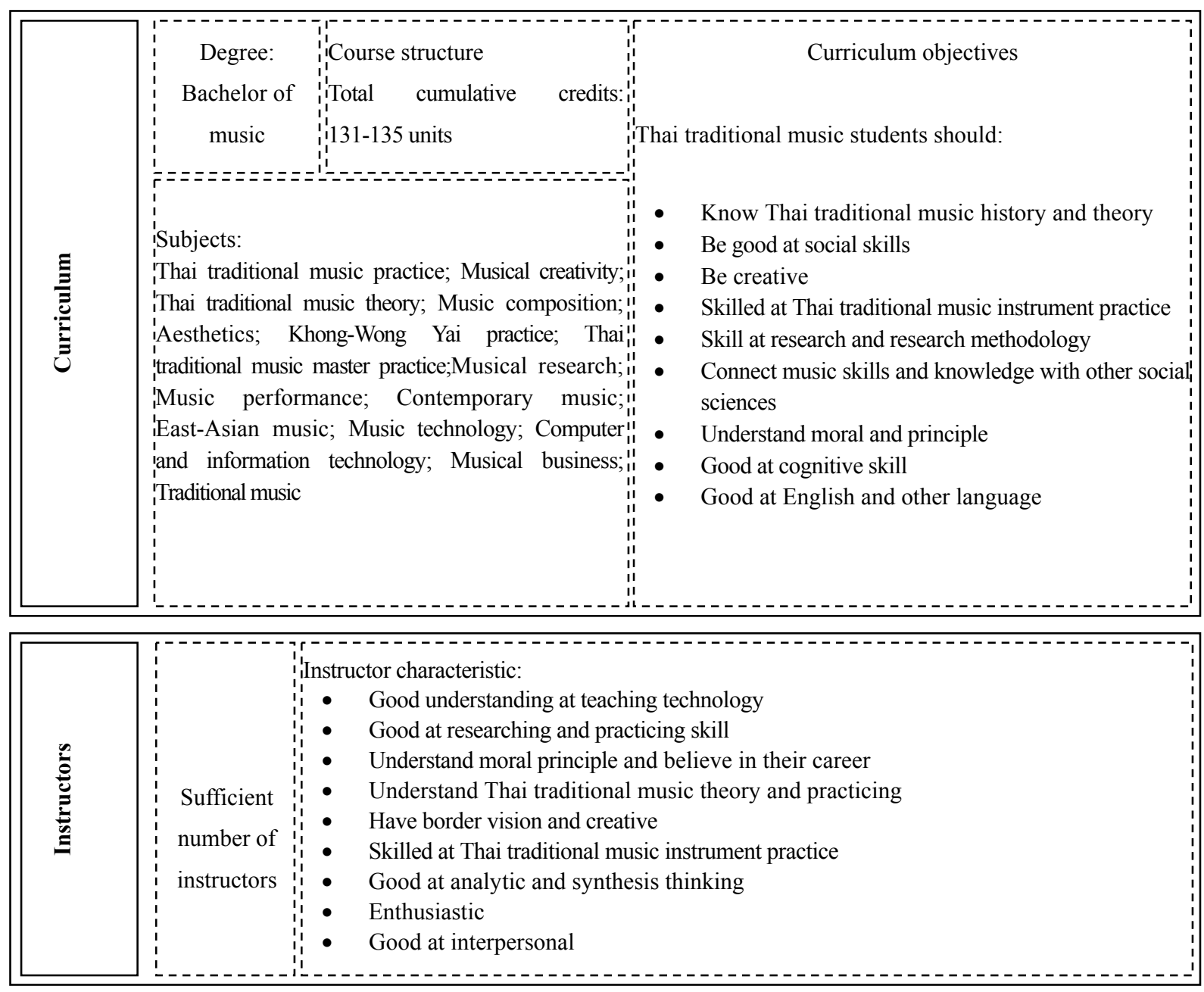

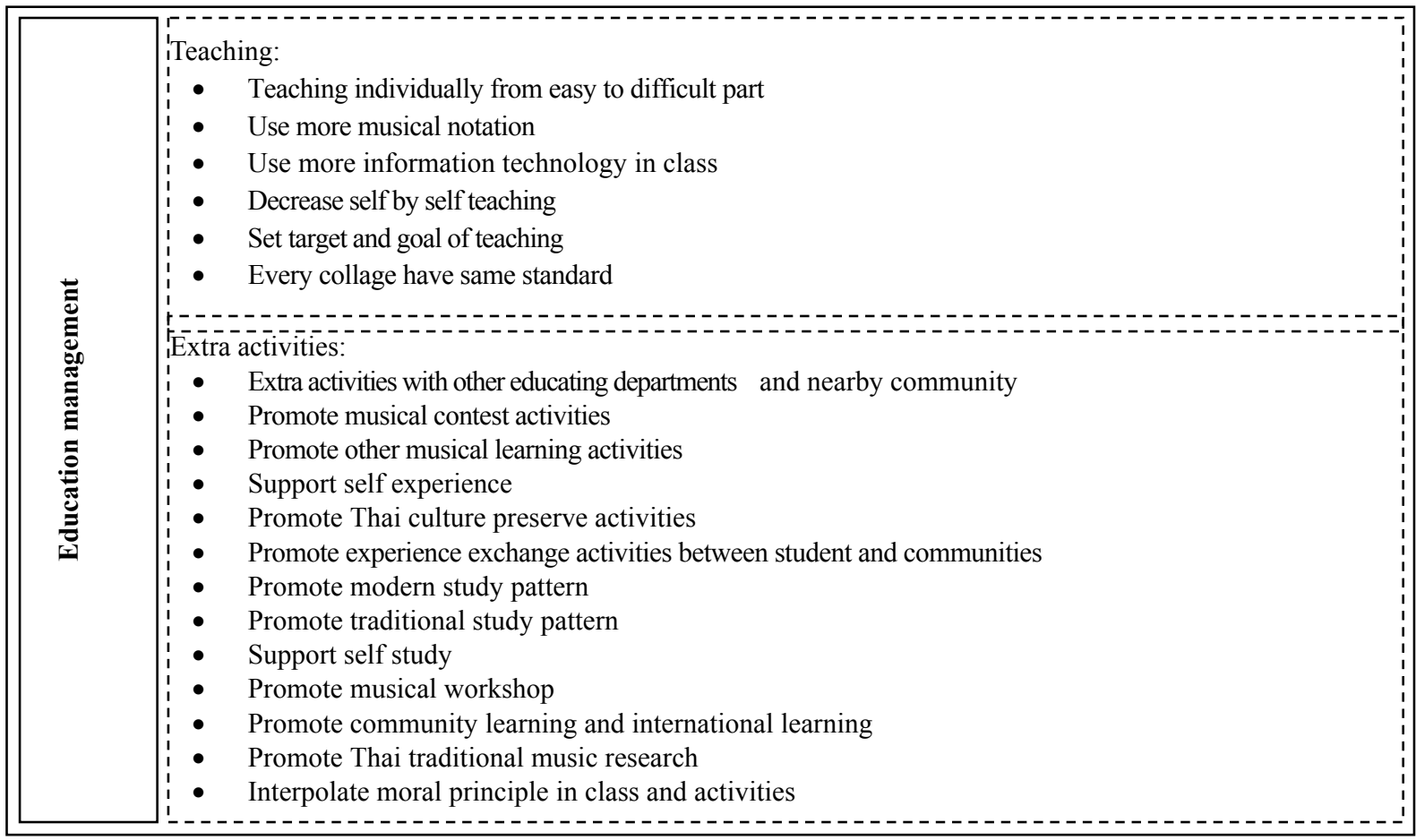




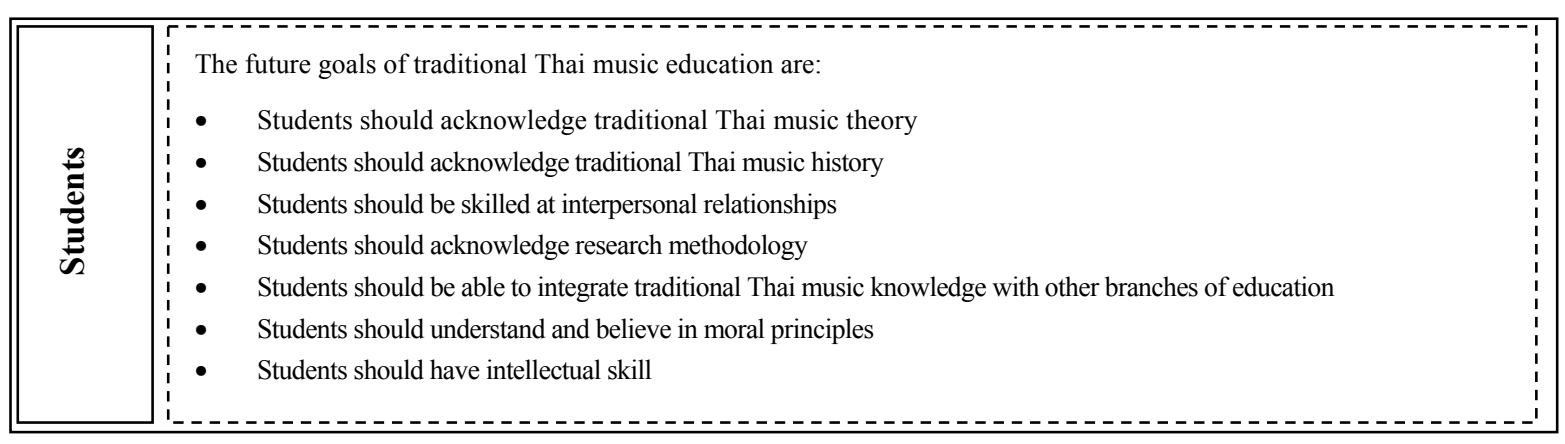

Figure 3. Future Thai musical education trends

\section{Discussion}

Thai traditional music education these days has different curriculum names in order to clearly define the course detail and distinctive points, which is connected with the trends of musical education in graduate study by Wathid Suwansomboon (2004). He said that the musical education in graduate study will branch and integrate with other sciences or majors. The Thai traditional music study is divided into 5 major subjects: aesthetics, Thai traditional music theory, Thai traditional music history, Thai traditional music practice and character development.The education standard criteria can be used only in some parts of education management and standardization. This agrees withSudarat Chanlekha (2006), who said that the standardization of musical education can only be done in some parts of education management due to the lack of musical instruments, instructors and instruction media.

The Thai musical instructor qualifications state that they must be literate in Thai musical theory, skilled in Thai musical instruments and have good practical skill. Thisis related to the work ofNattineeSriwongtrakol, who said that teachers should be masterly in his or her department.Moreover, they must always seek new knowledge and techniques.Thai musical teaching and studying has different techniques and patterns, for example lectures and excursions in order to match the study objectives. This is related to Thisana Khammanee (2009), who said that teaching is a process by which the teacher issues the learning activities according to the objectives in different ways and using varied techniques.

\subsection{Future Thai Musical Education Trends}

The future goals of traditional Thai music education are:

- Students should acknowledge traditional Thai music theory

- Students should acknowledge traditional Thai music history

- Students should be skilled at interpersonal relationships

- Students should acknowledge research methodology

- Students should be able to integrate traditional Thai music knowledge with other branches of education

- Students should understand and believe in moral principles

- Students should have intellectual skill

The number of instructorsmust increase in order to meet student demand. This relates to the research of Wathid Suwansomboon (2004), which found that Thai education trendsmust be enlarged and extended both in number and quality. The traditionalThai music instructor characteristics should be more researcher, academic and developer. Moreover they must be sanctimonious and good at interpersonal relationships.

Teaching management in the future should concern about instruction sequences from easy to difficult and use more technology to make the course easy to understand. The teaching goal is to decline the number of self-study, but increase the musical notation classes. Thai traditional musical study can also be divided by age of instructor, such as elder instructor, same-age instructor and young instructor. This is connected with the work of Chompoonuch Roumchat (2005), who said that education management in the next century will be concerned with the combination of theoretical study and practice.

The learning support activities should be focused on student skill expression, since these activities will enhance confidence and experience, for example traditional Thai music contests. According to Comprehensive Musicianship (Suthachrittra, 1993), experience causes understanding.

The Thai musical students should have at least basic knowledge and understanding of traditional Thai music theory and musical instrument practice. From the research of Kwanchai Hely (1990), the major problem of Thai music education is the lack of basic student knowledge. Thai music education in the future should focus on 
contemporary music, which relates to Eva Georgii-Hemming and Maria Westvall (2010). The two scholars said that musical students are more interested in popular music than traditional music.

\section{Suggestions}

\subsection{General Suggestions}

- The research can be an information source for Thai traditional music curriculum development.

- The musical colleges can use the information as basic information in education policy setting.

- The research can be used as base information to standardize Thai traditional music education and development.

6.2 Suggestions for Further Study

Further study should consider:

- The trends of traditional Thai music special tract development

- Comparative management of traditional Thai music education in undergraduate and further education.

- The characteristics of traditional Thai music study, for example basic knowledge level, by conducting comparative study of traditional Thai music and education science.

- In-depth research about traditional Thai music education management and trends.

\section{References}

Anderson, L. W. (1989). The Effective Teacher. New York: McGraw-Hill.

Bobbitt, F. (1918). The Curriculum. Boston: Houghton Mifflin.

Brown, J. W. (1973). A.V. Instruction Technology Media and Method (4thed.). New York: McGraw-Hill.

Helay, K. (1990).Condition and problems in Musical study in Thailand [in Thai]. Bangkok: Chulalongkorn University Press.

Roumchat, C. (2005).Future of teacher curriculum in next century (2007-2017)[in Thai]. Bangkok: Chulalongkorn University Press.

Suthchit, N. (1989). Musical teaching psychology [in Thai]. Bangkok: Chulalongkorn University Press.

Suthchit, N. (1993). Musical teaching behavior [in Thai]. Bangkok: Chulalongkorn University Press.

Suthchit, N. (1997). Musical activities for teacher [in Thai]. Bangkok: Chulalongkorn University Press.

Suthchit, N. (2004). Thai traditional musical history [in Thai]. Bangkok: Chulalongkorn University Press.

Suwannasomboon, W. (2004). The trend of Thai traditional musical study in graduate level in Thailand [in Thai]. Bangkok: Chulalongkorn University Press.

Wongsuwan, K. (2006). Thai traditional teaching process and technique wisdom in Rajaphatbansomdejjhaophraya, Thailand [in Thai]. Bangkok: Chulalongkorn University Press.

\section{Copyrights}

Copyright for this article is retained by the author(s), with first publication rights granted to the journal.

This is an open-access article distributed under the terms and conditions of the Creative Commons Attribution license (http://creativecommons.org/licenses/by/3.0/). 